\title{
PHENEUS AND THE PHENEATIKÉ.
}

AT three o'clock on the afternoon of July 6th, 1901, I stood at the extreme edge of the col between Mount Skipieza and Mount Saita, staring with a mixture of incredulity, irritation, and interest at the scene before me. Wherc I had expected to see the lake of Pheneus, a blue expanse of twenty-five square miles of water, there lay a fertile stretching plain, for the most part a blaze of golden corn, while here and there a white point of light shewed where a fustanella'd harvester was at his peaceful toil. Nearer, the corn gave place to an ugly foreground of sun-cracked clay, while just at my feet, stretching from side to side of the narrowing valley, lay a mere ribbon of slatecoloured water-all that is left of the lake of Pheneus to-day.

I knew that such changes in its condition had been noted by travellers from Pausanias downwards, but this last and I believe final disappearance of the historic lake seems to have passed without notice in Athens and elsewhere. Believing that a short account of this singular natural feature of the Peloponnese and of the changes to which it has been subjected would not be wanting in geographical and historical interest, I marle such survey and enquiries as were possible on the spot and have since collected what I could find written on the subject. The story of the lake or plain will be more readily intelligible by a brief description of the neighbourhood, which the accompanying sketch-map (Fig. 1) will make clear.

\section{I.}

The plain itself, its limits sharply defined by the surrounding mountains, is shaped and orientated somewhat like a miniature African continent. From N. to S. it measures about $7 \frac{1}{2}$ miles; from E. to W. rather less-the measurement being taken at such a point as to include its western arm or bay.

The eastern barrier of the lake is a great southern spur of Mt. Kyllene which, stretching southward under the ancient names first of Saepia, then of Geronteion, then of Sciathis, ${ }^{1}$ separates the valley of Pheneus from that of

1 From a supposed similarity of names, Leake (Travcls in Morea, iii. 142, 151) and most subsequent writers identify the ancient Sciathis with the modern Saita and consequently the ancient Oryxis with the modern Skipieza. Curtius (Peloponnesus, i. p. 187) transpioses these identifications, thinking that Oryxis must mean the 'mountain of the canal,'

\footnotetext{
i.e. the mountain containing the S.W. Katavothra to which the cunal or causeway of Herakles led. This seems in itself probable, and if Saita, like the other monntains' names of the district, e.g. Zereia and Skipieza, is a Sclav word, it would hardly be a corruption of Sciathis.
} 
Stymphalus. The pass to Stymphalus lies between Geronteion and Sciathis. This great outwork of Kyllene in its southern portion is to-day called Skipieza. Facing it on the S.W. side of the lake rises the mass of Saita, and due south of the lake, and consequently between Skipieza and Saïta, is the steep track from Orchomenus by which Pausanias reached the Pheneatiké.

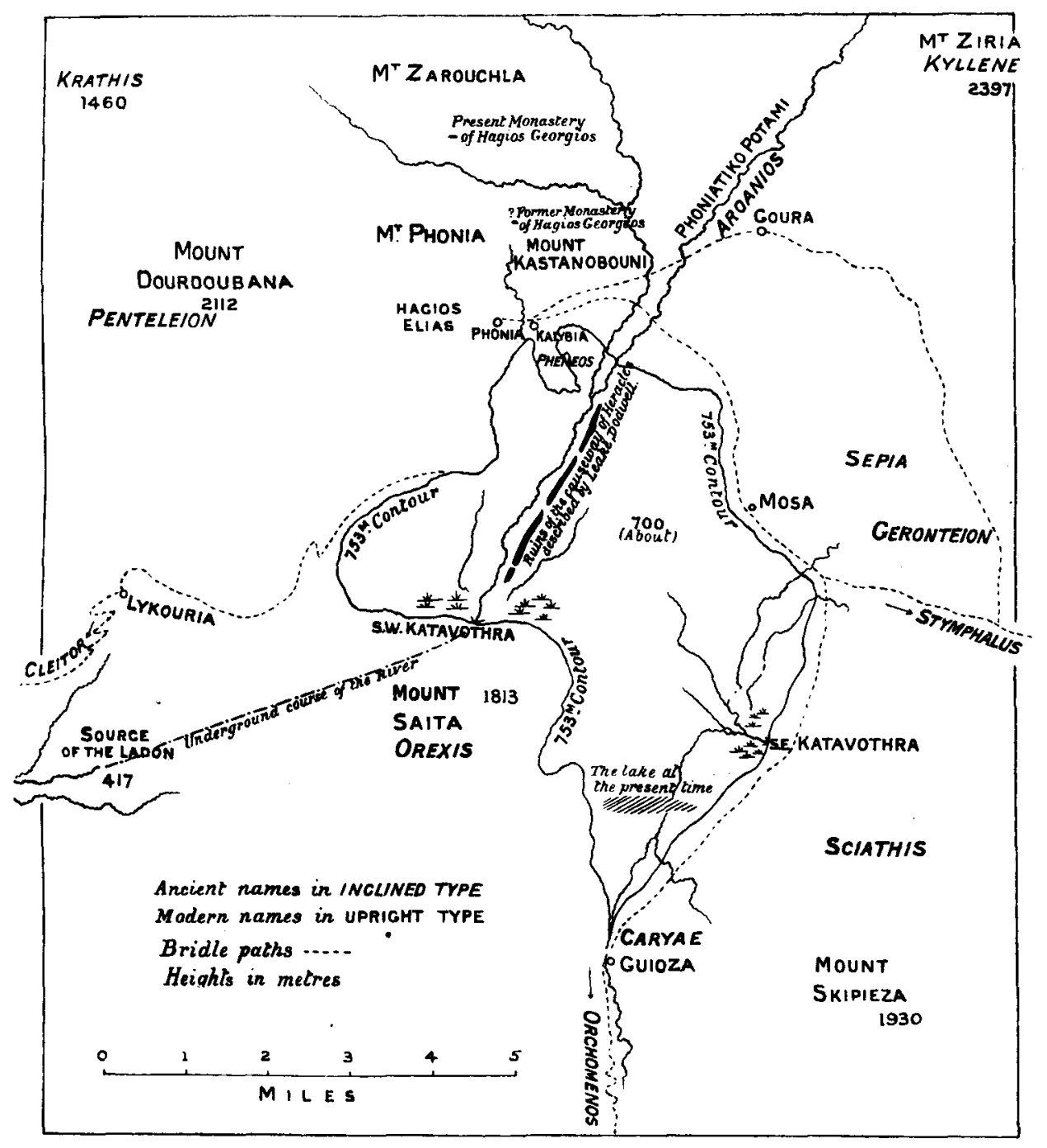

Fig. 1.-Sketch-Mat of the District of Lake Phonia.

N.W. of the lake and overhanging ancient Pheneus and modern Phonia is Mt. Dourdoubana, which forms part of the chain called in antiquity Penteleion. Between this and Saita lies the pass to Lykouria and Kleitor. Only at its northern angle is there any real break in the circle of the 
hills. Here two streams formerly entered the lake side by side. Their present junction is to the $\mathrm{S}$. of ancient Pheneus. Of these the Phoniatiko Potami, called in antiquity the Aroanios or Olbios, ${ }^{2}$ rises at the modern Karya, ${ }^{2 b}$ which lies ten miles to the N.E. of the lake, and flows thence in a uniformly S.W. direction to Pheneus. The other, a smaller stream, winds down to the plain between the two spurs of Krathis now named after the villages of Phonia and Zarouchla respectively. The only other stream of any volume is the fine cataract that comes down the gorge of Guioza, the ancient Caryae or Caphyae, to the extreme south of the lake.

It will be seen from this enumeration that no other than a subterranean outlet is possible for the waters, and of these singular natural features of Arcadia there are two striking examples on the S.W. and S.E. of the lake, at points roughly corresponding, if the parallel of a miniature African continent be remembered, to the mouths of the Niger and Zambesi. In antiquity

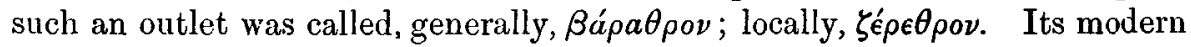
name is катаßó $\theta$ a. Of these Katavothrae Leake ${ }^{3}$ gives the most comprehensive list, and Philippson ${ }^{4}$ the most scientific account. They seem to be confined to the limestone area, and may take the form either of a porous layer through which the water percolates imperceptibly, or of a more or less open chasm into which it descends in a stream or cataract. In most cases the streams thus lost to sight have no recognisable outlet, and we must suppose that they disappear to feed the complex underground system of drainage and storage which belongs to the natural economy of the earth. Such outlets are unfortunately liable to various forms of obstruction. In the first place they may be choked by débris-trees, carcases, and the like -carried thither in time of flood or storm. Not very successful efforts have been made to obviate this danger by placing gates or gratings of iron at the entrance. These have sometimes caused the very disasters they were designed to obviate, by arresting matter at the mouth of the channel, which might if left to itself have found its way safely through the underground outlet. Again, obstructions caused by a subsidence or other seismic movement have occurred, but such of these as have been observed have been of very temporary effect. Lastly, the most insidious and disastrous obstruction is that caused by the gradual deepening of alluvial deposit at the opening.

Of the two Katavothrae at Pheneus the S.W. is the more important. It is the main outlet of the waters, and the goal of the ancient canal and embankment, discussed below. But from its now indisputable connection with the source of the Ladon it is of fatal interest in the forgotten history of Olympia, now sleeping quietly in the sun forty miles away in Elis, but for centuries at the mercy of this terrible and unsuspected foe. As a rule the S.E. Katavothra formed as now the exit of the stream which descends from

\footnotetext{
2 Possibly Olbios niay have been the name of the Zaronchla tributary. The Anias of Strabo (Gcographica, viii. 389) may be only a blunder for Aroanios.

2b The ancient Caryae is at the south of the
}

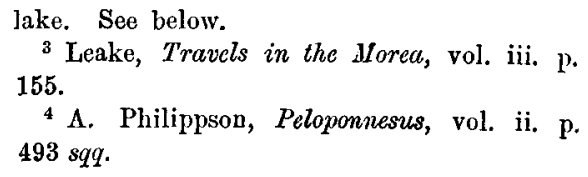
155.

4 A. Philippson, Peloponnesus, vol. ii, p. $493 s q q$. 
Guioza. Its course underground is uncertain, but it may possibly be connected with Lake Stymphalus. Its position makes this probable, and I learn ${ }^{4 a}$ now that in 1899, when the Pheneus lake was fast falling, the lake of Stymphalus was remarkably full. I should imagine that on those occasions when the lake has emptied without doing damage in the Alpheios valley the main body of the waters have made their escape through this outlet-otherwise we must suppose that the alluvial deposit in Elis is now so deep that the waters even in flood-time do not rise above it.

Before turuing to the history of the Pheneatiké there remains one

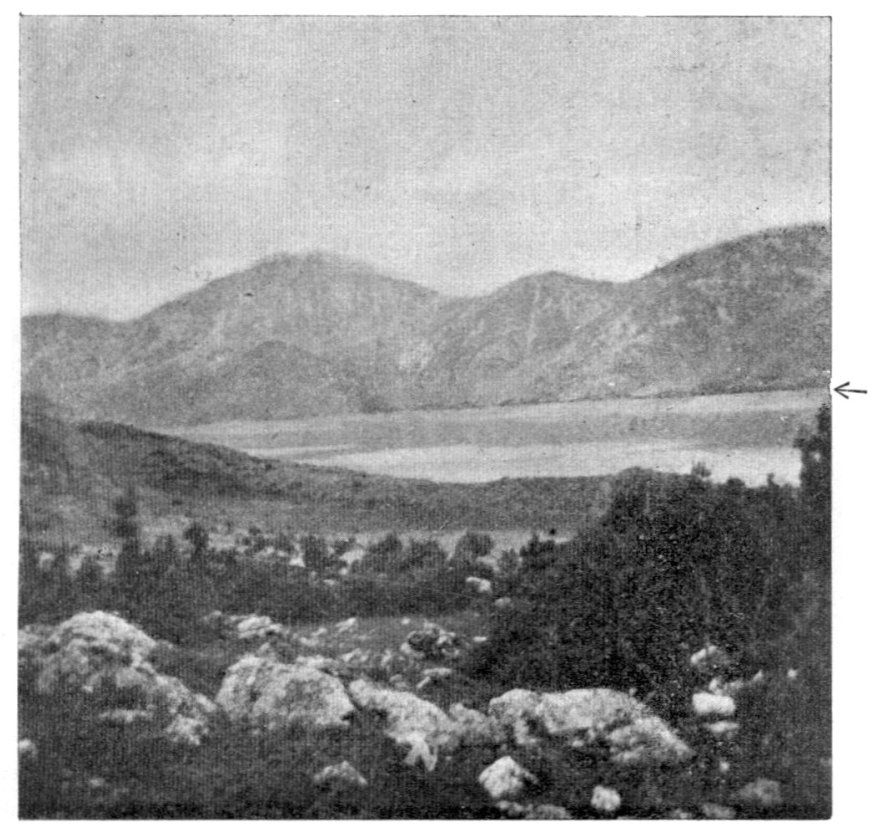

Fig. 2.-The Old Water-line of Lake Phonia

(Runuing to the left from the point marked $\leftarrow$ ).

most interesting feature to discuss. Travellers from Pausanias onward have noticed the existence of a sharply-defined line passing at an even level round the contours of the hills, at a height which has been very variously estimated. $^{4 b}$ This phenomenon, which is very striking when seen from a nearer point of view, is just visible in Fig. 2, reproduced from a photograph taken during the last subsidence of the lake and kindly lent by Professor Ernest Gardner. ${ }^{40}$ The most natural explanation is that the line is, what

4a From Mr. J. H. Hopkinson who visited the Pheneatiké at this date.

tb Partly no doubt from the fluctuating level of the lake from which it has been calculated.

4c I am also indebted to him for the other photograph (Fig. 3) which gives a general view of the lake recalling something of the charm of this Arcadian Switzerland. The women in the foreground are digging gypsum. 
Pausanias took it to be, the trace of an old water level. Leake ${ }^{5}$ thinks it to be too high for this, and suggests that it is due to the process of evaporation, adding that he has seen similar phenomena elsewhere. It is rather singular that Leake should bring forward this objection of too great altitude, as (1) he estimates the height of the marks at 50 feet above the plain, an estimate so erroneously low that it looks like a misprint for metres, and (2) he quotes with apparent belief a rumour that the water did on one occasion reach the height of 300 feet. Neither of these statements seems to be compatible with his view that the marks are too high to be a water level. A second

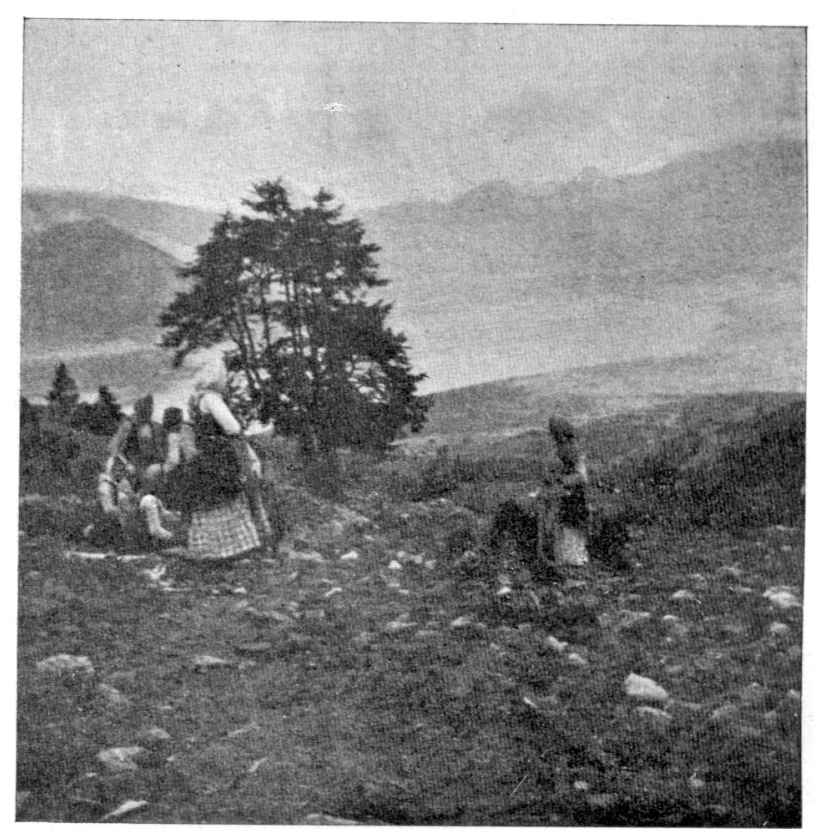

Fig. 3.-Lake Phonia.

(Women in the foreground digging gypsum.)

objection to the theory that the line is a water level, also noticed by Leake, seems to me to be more cogent. So sharply cut is the line that looking up at it one's natural impression is that the lake must have remained at that level and no other for ages together, to produce such clear, solitary, and lasting trace of its presence. Now it will be seen from the passages referred to below that the record of the lake where it exists suggests a directly opposite conclusion, viz. that its normal state is that of rising or falling. ${ }^{6}$

5 Leake, Travels in the Morea, vol. iii. p. 150 .

${ }^{6}$ Other possible indications of this are the absence of fish in the lake and of any kind of aquatic tradition among the inhabitants. 
It seems to me that the line as we see it shews the level to which for innumerable alternatious the water rose before sinking. In what manner precisely that limit was fixed it is difficult to determine. Mr. J. H. Hopkinson has suggested to me that there may exist or have existed a second and higher channel (Fig. 4) communicating with the Ladon from the level of the lines which would thus become a ne plus ultra limit, and acquire as the ages

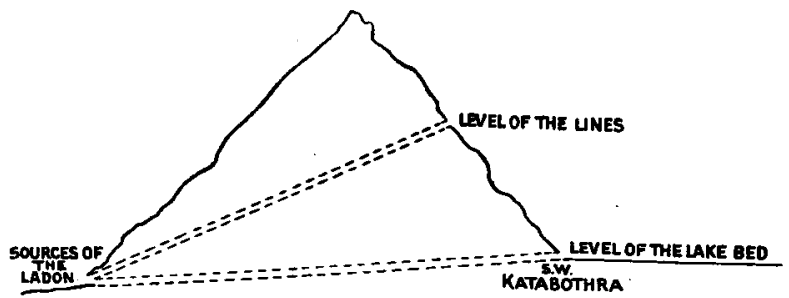

Frg. 4.

passed the sharp definition otherwise inexplicable in a fluctuating lake. Professor Ernest Gardner supposes that the subterranean passage does not continuously descend but rises in its course to the level of the lines (Fig. 5) forming a natural syphon which would prevent the waters of the lake from rising above the highest part of the hidden channel. But this, though it would fix an upward limit to the lake, and so account for the definition of

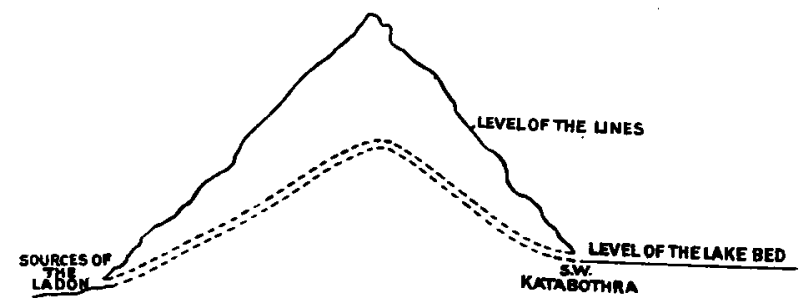

FIG. 5.

the lines, obviously would not suit the conditions observed and recorded in history, and indeed existing at the present time. We must therefore suppose that at some time anterior to the first records of the lake, the course of the channel which had produced the lines was modified, possibly by seismic disturbance, to its present condition, which from the absence of water in the lake bed must be one of continuous descent to the source of the Ladon. ${ }^{7}$

\footnotetext{
7 Another explanation was devised by W. G. Clark (Peloponnesus, p. 318) who thought that the line merely shewed the juncture of two geological strata, but this seems to me impossible owing to its length and absolutely even
}

level. Philippson also, who writes with geological knowledge, is quite clear as to the line being a water-line. Clark is right however in saying that the lines do not appear at the north end of the lake. 
II.

The natural features of the Pheneatiké being such as I have described, it seems probable that alternations between lake and plain have existed from a period long before the dawn of history.

Mythologic indications may be noticed first. Curtius conjectures, ${ }^{8}$ in a manner more familiar in the middle of the nineteenth than the beginning of the twentieth century, that the legend of Herakles descending from Pheneus to ravage Elis is a natural myth, and that we may recover in this story a lost record of some early outburst of the lake attended with the same fatal consequence for Olympia that we know to have followed in later history. But the association of the sojourn of Herakles in Pheneus with his descent upon Elis rests on very slight foundation-the fact that Pausanias ${ }^{9}$ saw the reputed tomb of Iphikles, brother to Herakles and his comrade-in-arms, on this Elean expedition, at or near Pheneus. Further, in the story of his sojourn in the Pheneatiké, Herakles plays the rôle of a Prometheus, the contriving friend of man, taming savage nature for his good, rather than that of a malignant natural foe. Indeed, his causeway or canal was meant to obviate the very catastrophe of which Curtius rather unkindly accuses him. There are, however, other interesting indications in the mythology of the district. The cults, ${ }^{10}$ as Pausanias enumerates them, seem peculiarly fitted to its singular character. Poseidon is a deity proper for a horse-feeding plain or a stretching sea, Demeter for peaceful cornland or for that underworld whose chasms yawn on either side the lake, Hermes for a folk more than any other at the mercy of the change and chance of life. ${ }^{10 \mathrm{~b}}$

The ancient citadel of Pheneus at the northern end of the lake is mentioned once by Homer ${ }^{11}$ in the Catalogue, and once by Virgil ${ }^{12}$ where Evander recalls the sojourn of Anchises and Priam at his Arcadian home. The citadel stood, as we learn from Pausanias, on what one still naturally speaks of as a peninsula jutting out from the N.W. angle of the plain. So inadequately does this insignificant conical hill fit the description of Pausanias, who speaks of it as precipitous on every side and requiring little artificial fortification, that as early as 1806 Dodwell tried to identify as the real citadel a height, bearing the omnipresent name of Elias, which rises above the modern village of Phonia. The remains here, however, appear to be of the least conclusive character, and it is scarcely probable that the acropolis in the ordinary sense of the word would be so far from and above the town

\footnotetext{
Curtius, Peloponnesus, vol. i. p. 188.

${ }^{9}$ Pausanias, viii. 14.

${ }^{10}$ Bursian, Geographie von Griechenland, ii. p. 199.

10b He would not be less appropriate in his Arcadian character of the $\nu \delta \mu \nu$ s $\theta \in \dot{b} s$. See next footnote.

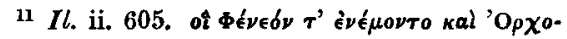

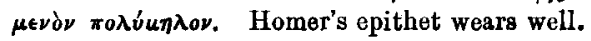

I gratefully remember a stirrup cup of sheep's milk given me by shepherds on Orchomenus when leaving for Pheneus.

12 Virgil, Aen. viii. 165. Another survival of the Trojan connection with Pheneus is the burial-place of Anchises in the low ridge which separates the plains of Mantineia and Orchomenus. 
proper. According to Leake, though it does not seem to be noticed by other travellers, the modern village occupied the ancient site till recent times. This occupation may in a measure account for the discrepancy between the account of Pausanias and the site as it is to-day. All traces of the lower town described by Pausanias as lying at the foot of the hill have disappeared. The stadion one would suppose lay in the valley of the Aroanius. There is hardly room for it elsewhere. ${ }^{13}$

It may seem strange that in the brilliant and crowded pageant of Greek history no event of importance either in peace or war is associated with what on the map of Greece appears as one of its most striking features. The natural battlefields of the Peloponnese, however, lie to the south, and, spacious arena as the lake bed seems, a commander might well hesitate to risk his force in the tortuous defiles which form its communication with the outer world. ${ }^{14}$ Again, these and its liability to periodic devastation may have made and kept it a small and isolated community in times of peace.

The earliest direct reference to the peculiar features of the lake seems to be a sentence in the writings of Theophrastus, ${ }^{15}$ the pupil, friend, and heir of Aristotle. From his remark that the various forms of vegetation at Pheneus, when destroyed by inundation, renew themselves on the same spots where they had formerly grown, we gather that in his day the alternations between lake and plain were fairly frequent. Eratosthenes, a Greek geographer of the next century quoted by Strabo, ${ }^{16}$ was aware that the S.W. Katavothra was connected with the source of the Ladon, and attributes in set terms the destruction of the site of Olympia ${ }^{17}$ to the waters of the lake escaping by that channel.

A comparison of the references by writers about the beginning of our era makes it seem likely that at that period the lake was full. Diodorus Siculus says that in former times the Aroanius was lost in a subterranean

13 As the name Pheneus is somewhat loosely used by several writers, I append a list of the localities which have at one time or other borne the name.

(i) The whole district of lake or plain with the liamlets on the enclosing mountains. This

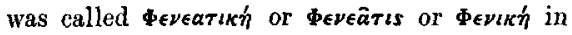
antiquity, and is to-day the $\delta \hat{\eta} \mu o s$ фeveov.

(ii) The citadel on the conical hill jutting out in to the lake at its northern angle. This was the acropolis described by Pausanias. It was inhabited until the eighteenth-century in. undations.

(iii) The district near the lake bed at the foot of this hill. This was the $\pi \boldsymbol{\alpha}_{\lambda}$ s described by Pausanias. Close to it is the modern village $\mathrm{K} \alpha \lambda \dot{v} \beta \iota a$, which is, I believe, to bear in future the official name $\Phi \in \nu \in \delta ́ s$.

(iv) The modern village of \$ovia. This, with the adjacent hamlet of Bixia overlooks the ancient citadel from the southern slope of $M t$.

\section{Dourdoubana.}

14 Polybius, Histor. Reliqu. iv. 11, mentions the failure of an Achaean army to hold the pass between Stymphalusand Orchomenus in 221 B.c., and (iv. 70) gives an account of the successful passage of a Macedonian force in B.c. 218 through the same pass in the middle of the winter.

15 Theophrastus, Hist. Plant. iii. 1.

16 Strabo, Geographiea, viii. 389.

17 This connection cannot be disputed. The necessity for an outlet of so considerable a stream as is inhnmed at the Katavothra, the respective positions of this and of the Ladon spring, lying six miles apart, with a fall of about 850 feet between the two, and the correspondence between the diminution of the lake and the increase of the stream make this connection clear. Cf. I. Ross, Reisen... durch Griechenland, p. 107. Cf. also Frazer, Pausanias, iv. p. 263. 
channel, as if in his day it flowed into the lake. Plutarch ${ }^{18}$ rallies Apollo for his injustice in sending a plague of waters on the Pheneus of his day, for the theft of the sacred tripod a thousand years before. Aelian ${ }^{10}$ also alludes to it as a lake. All these scanty references may well refer to one and the same inundation. Pliny ${ }^{20}$ implies nothing as to the condition in his time, but mentions alternations previous to his day. He attributes them all, probably erroneously, to seismic disturbance.

Pausanias ${ }^{21}$ gives us a fairly detailed and doubtless an accurate picture of the empty plain as he saw it, though he was unaware that the lake had existed so recently as the passages cited above would seem to shew. ${ }^{22}$ The canal of Herakles was, he says, 50 stades in length. The actual distance between Pheneus and the S.W. Katavothra is about $3 \frac{1}{2}$ miles, so that if the measurement given is accurate we must suppose its inception to have been some little way up the Aroanius Valley. It was in his time 30 feet in height, where unbroken, and seems to have been not so much an artificial channel excavated in the plain, as a huge mound crossing the lake bed in a general direction from N.E. to S.W., and designed in the first instance to prevent an irruption of the waters into the $\mathbf{E}$. and S. parts of the plain, and also to serve as a road or causeway. It no longer fulfilled its purpose in the time of Pausanias, being partly ruined, probably by the inundation mentioned above. Such causeways though of a ruder type and on a smaller scale are not infrequently found in Arcadia. One, which is, I think, ancient, crosses the northern plain of Orchomenos; another, which is of uncertain date, separates the plains of Tegea and Pallantium. ${ }^{23}$

From the day when Pausanias turned his horse's head to Pallene to the visit of Leake and Dodwell in 1806 the little valley has been without an historian. ${ }^{24}$ We do not know what catastrophes there attended the great earthquakes of the sixth century, nor under what circumstances that deep, even layer of earth was deposited on the banks of the Alpheios, part of which, never since disturbed, yet stretches from the Hippodrome to the Leonidaion at Olympia.

There exist, however, a few scanty indications of the condition of the lake towards the eighteenth century. The earliest maps of Greece afford more of the allegorical glory of Venice and Amsterdam than the interior

18 Plutarch, De sera numinis vindicta, xii.

19 Aelian, De nat. anim., iii. 58.

${ }^{20}$ Pliny, Nat. Hist, xxxi. 54.

21 Pausanias, viii. 14, 1-3.

22 I am not surprised that this should be the case when I remember my utter failure to extract local information worth the name about the last disappearance of the lake, which caunot have happened more than three or four ycars before my visit. But ef. the table at the end of this paper.

23 Pausanias, viii. 44, 5. Frazer, Pausanias, iv. p. 419 .

${ }_{24}$ I should imagine that the Pheneatike when once its barrier of mountains is passed is much to-day what it has always been. The good Hegoumenos of Hagios Georgios shewed me with pride a dusty collection of the visiting cards of chance travellers-scarcely one for a decade of years. I can call to mind no other part of Europe where life has gone on through the centuries with seemingly so little change, so little interruption from the outside world. 
features of the countries they represent, but two, a Dutch ${ }^{25}$ and a German ${ }^{26}$ map, published respectively in 1690 and 1720 , certainly shew the lake as a lake with the Ladon directly issuing from it. That the Venetians had fortified ancient Pheneus is probable, not only from the remains on the site but also from the numerous Venetian coins (Obv. Lion of S. Mark, Rev. Christ King) found in the neighbourhood. ${ }^{27}$

Boblaye, ${ }^{28}$ Neumann-Partsch, ${ }^{29}$ Curtius, ${ }^{30}$ and others all give records, derived probably from local tradition, of a very deep inundation early in the eighteenth century, in which an older monastery of Hagios Georgios, $300^{31}$ feet above the level of the plain, is said to have been submerged. It is possible however that this inundation has been greatly exaggerated. ${ }^{32}$ The altitude of the present monastery, and indeed of modern Phonia, would it is true seem to bear out the story, but Greek monasteries from both religious and political tradition are more often than not perched on almost inaccessible heights, and Phonia may have been placed where it is to escape malarial exhalation from the lake rather than the lake itself. ${ }^{33}$ If the figures are correct, it is not easy to estimate the danger afforded by a huge leaky cistern, containing the vast volume of water implied in this measurement, poised high above the Peloponnese.

When we come to the last century the record is fairly continuous. Leake $^{34}$ and Dodwell ${ }^{35}$ who visited Pheneus in 1806 found a swampy plain still traversed, as when Pausanias saw it, by a partially ruined causeway. Gell, ${ }^{36}$ who must have been there shortly after, speaks of this as ' a road conducted along a magnificent mound,' and gives a very interesting view of the lake (which is here reproduced, Fig. 6) under these circumstances. This however gives the impression that the causeway led to the extreme $\mathbf{S}$. of the lake rather than to the S.W., Katavothra, which I do not think can ever have been the case.

25 The Peloponnesus, G. and L. Valk, Amsterdam, 1690.

${ }^{26}$ Id. M. Seutter, Angsburg, 1720. Both these are in the British Museum. My faith in maps as contemporary evidence has however been shaken. The largest and most expensive of modern guides to Greece, published with all the resources of easy communication and travel at its command, gives in its 1901 edition a brilliant blue lake of some 25 square miles in extent where no lake exists at all. Nimium ne crede colori.

27 Bursian, Geographie von Griechenland, ii. p. 200.

${ }^{28}$ Le Puillon de Boblaye, Recherches géographiques sur les ruines de la Morée, p. 153.

29 C. Neumann und J. Partsch, Plyysikaliseĩe Geographie von Griechenland, p. 252.

30 E. Curtius, Peloponnesus, ii. p. 189.

3) Neumann and Partsch, loc. eit. give the depth of the waters as 252 metres.
32 One weak point of the story is that the present monastery of Hagios Georgios is obviously older than the date assigned to the inundation. The situation of this monastery is surely one of the most beautiful in Greece. A curved bastion of Mt. Crathis reaches out nearly to the lake, rising out of an undulating mass of plane-trees, cypresses, and poplars, broken here and there by the scattered fields of the monastery, the irregular red-tiled roofs of which nestle high above under the very crest of the spur.

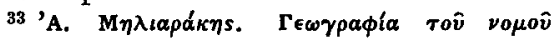

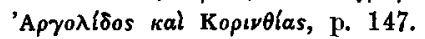

${ }^{34}$ Leake, Travels in the Morea, -vol. iii. p. $135 s q q$.

${ }^{35}$ Dodwell, Tour in Greces, vol. ii. pp. 436-441.

36 Gell, Itinerary of the Morea, p. 151 sqq. Journey in the Morea, p. 373 sqq. and Plate facing p. 380. 
What happened in the valley, after these visits early in the century, seems to have been briefly this. Either Drama $\mathrm{Ali}^{36 \mathrm{~b}}$ the last bey of Corinth, or an inferior Turkish pasha who kept up some kind of fortress at Mousa on the E. side of the lake, placed iron gates or gratings over the months of the Katovothrae for the obvious purpose of preventing their obstruction. When the Pheneatike was evacuated by the Turks, these gates were recklessly destroyed by the Greek peasantry in an outburst of undiscriminating hate for their former masters. The result was that shortly after the War of Independence the Katavothrae began to close and the lake began to rise. ${ }^{27}$

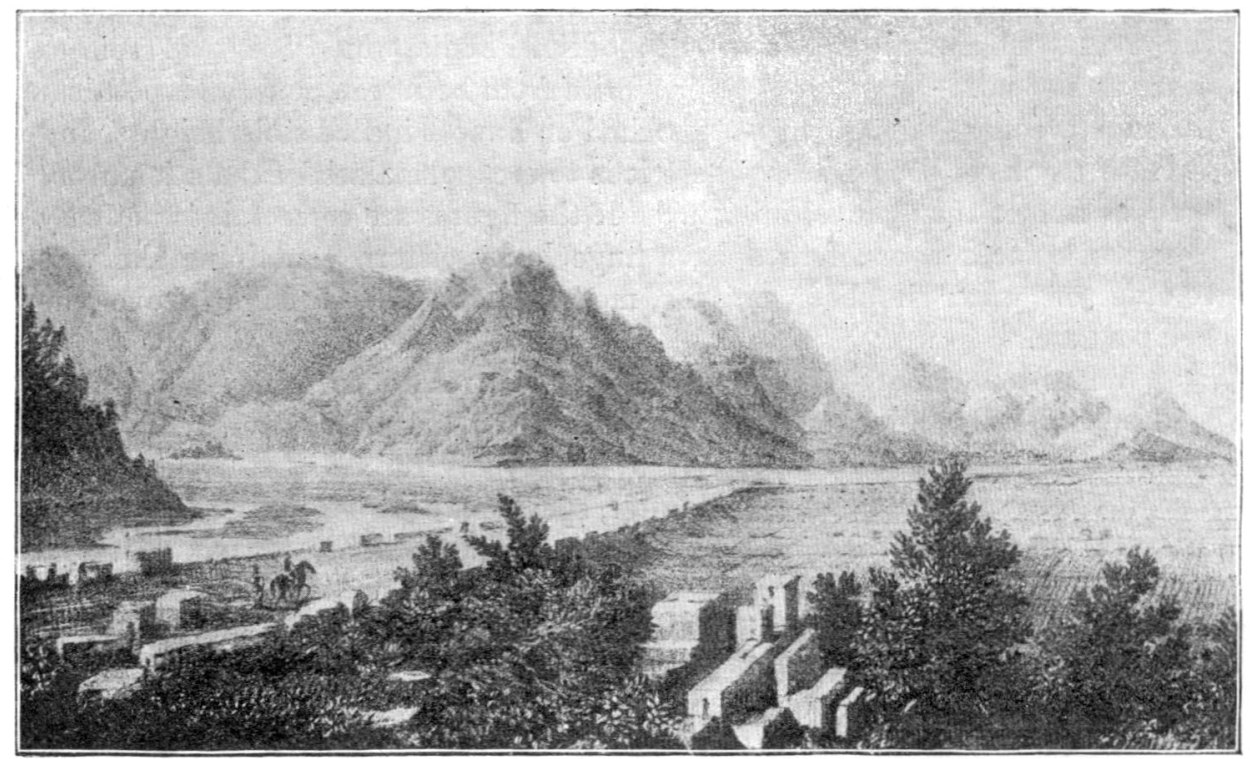

Fig. 6. - View of I. Phunia.

(From Gell's Journey in the Morea.)

It was still rising when the French map ${ }^{38}$ was made in 1829 . Boblaye gives the height of the lake above the sea level as 753 metres, its depth being about 50 metres.

During this time the Ladon stream was dry. The water continued to rise till Jan. 1st, 1834, when the S.W. Katavothra suddenly opened, the Ladon became again a raging torrent, and part of the site of ancient Olympia was again flooded. This reappearance of their lost pastures coincided with the arrival of the newly chosen king of Greece, and was hailed by the inhabitants as a happy omen of the new era. The prosperity of Pheneus

36b Neumann and Partsclu, p. 252.

37 This seems on the face of it more likely than the local tradition to the effect that the placing of these gates was a final act of malice on the part of Drama Ali, and intended to cause the disaster that followed.

${ }^{38}$ Carte de la Grice. . . . . par les offieiers du Corps d'Etat-Major. Paris, 1852. 
was short-lived. Clark ${ }^{38 b}$ was told that the malice of the people of Lykouria was the cause of the next rise of the lake. If this is true we have history repeating itself, for the control of the water supply seems to have been a fruitful cause of ill-feeling between the communities of S. Arcadia in classical times. But whatever the cause, the inhabitants in 1838 saw the waters again encroaching on the scene of their recent toil, and from that time forward all travellers describe it as a lake. ${ }^{39}$ In the last inundation it seems to have reached its highest level about the year 1880. The last published account of the lake based on personal knowledge is that of Mr. Frazer, ${ }^{40}$ who visited the Pheneatike in the autumn of 1895 , and devotes to the lake and its surroundings some of those passages of graceful and informing description admired by all readers of his Commentary.

The lake was sinking then and must have sunk rapidly since, for at the time of my visit, ${ }^{41}$ in July of this year, all that remained of it was a strip of slate-coloured water, perhaps 200 yards across, at the extreme southern end of the bed. A cairn on the level just below Guioza mentioned by Gell still exists, and at this point the water marks, if such they are, are extraordinarily clear. I put them at $\mathbf{1 5 0}$ feet above the plain, which accords fairly well with what other travellers have estimated. Either the remains of the causeway must have been hidden in the thickly standing harvest, or else the very ordinary trodden earthen track, along which I rode, but little above the level of the plain, must be all that is left of it. Certainly there is no conspicuous mound crossing the plain to-day where Leake and Dodwell would lead one to expect it.

Appended on the following page is a list of such fluctuations of the lake as have been recorded, with the authorities for them. Exact reference to these has already been made in the footnotes.

\footnotetext{
3\&b Peloponnesus, p. 316.

39 Most of these have been already cited, but cf. also :-

F. Aldenhoven, Itineraire descriptif de l'Attique, p. 295 sqq.

W. Vischer, Erinnerungen.... aus Griechenland, p. $494 s q q$.

G. F. Welcker, Tagbuch einer griechischen

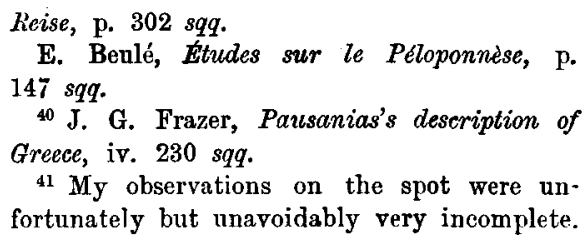


TABLE OF RECORDED FLUCTUATIONS OF THE LAKE.

\begin{tabular}{|c|c|c|}
\hline DATE. & Condition of Lake. & AUTHORITIEs. \\
\hline Before the Christian Era. & Unrecorded alternations. & $\begin{array}{l}\text { [Indications in Theophrastus and Era- } \\
\text { tosthenes]. }\end{array}$ \\
\hline $\begin{array}{l}\text { At some period between } \\
1 \text { and } 150 \mathrm{A.D} \text {. }\end{array}$ & Full. & Diodorus Siculus. Plutarch. Aelian. \\
\hline Cir. 175. & Empty. & Pausanias. \\
\hline $\begin{array}{l}\text { Between ancient and mod- } \\
\text { ern times. }\end{array}$ & Unrecorded alternations. & $\begin{array}{l}\text { [Indications:-The great earthquakes of } \\
522,561 \text {. The abnormal inundations } \\
\text { at Olympia.] }\end{array}$ \\
\hline $\begin{array}{l}\text { Early part of eighteenth } \\
\text { century. }\end{array}$ & Very full. & $\begin{array}{l}\text { Some early maps. Boblaye. Neumann } \\
\text { and Partsch. Curtius. (All appar- } \\
\text { ently from local tradition). }\end{array}$ \\
\hline $1806-1820$. & Empty. & Leake and Dodwell. Gell. \\
\hline $1820-1834$ & Rising. & $\begin{array}{l}\text { The French Staff Map. Neumann and } \\
\text { Partsch. }\end{array}$ \\
\hline Jan. 1st, 1834. & Sudden fall. & $\begin{array}{l}\text { Boblaye, Aldenhoven, Welcker, Beulé, } \\
\text { Curtius, Vischer, Clark, Bursian, } \\
\text { Neumann and Partsch, Philippson, }\end{array}$ \\
\hline $1834-1838$. & Empty. ' & $\begin{array}{l}\text { Meliarakes, Frazer. These authors } \\
\text { write in varying degree of fulness, }\end{array}$ \\
\hline $1838-1880$. & Rising. & $\begin{array}{l}\text { but from a consensus of their remarks } \\
\text { these dates may be relied on. }\end{array}$ \\
\hline $1880-1895$. & Falling. & Frazer. \\
\hline 1901 July-August. & Empty. & $\begin{array}{l}\text { Local information communicated to the } \\
\text { author. }{ }^{42}\end{array}$ \\
\hline
\end{tabular}

42 I learn this from my friend Mr. Christos Lazaropoulos of Levidi near Orchomenos, who since this paper was written was so kind as to send me further particulars. The last disap- pearance of the lake was, as before, due to natural causes, but steps are said to have been taken to keep the Katavothrae permanently open.

John ff. Baker-Penoyre. 